\title{
Degradation of Thyroid Hormones
}

\section{by Phagocytosing Human Leukocytes}

\author{
Seymour J. Klebanoff and William L. Green \\ From the Department of Medicine, University of Washington School of \\ Medicine, Seattle, Washington 98195
}

A B S T R A C T Thyroxine ( $\left.T_{4}\right)$ and triiodothyronine $\left(\mathrm{T}_{3}\right)$ are rapidly degraded by a purified preparation of myeloperoxidase (MPO) and $\mathrm{H}_{2} \mathrm{O}_{2}$ with the formation of iodide and material which remains at the origin on paper chromatography. Deiodination by $\mathrm{MPO}$ and $\mathrm{H}_{2} \mathrm{O}_{2}$ occurs more readily at $\mathrm{pH} 7.0$ than at $\mathrm{pH} 5.0$ in contrast to iodination by this system which is known to occur more readily at $\mathrm{pH} 5.0$ than at $\mathrm{pH}$ 7.0. Degradation is inhibited by azide, cyanide, ascorbic acid, and propylthiouracil. Methimazole stimulates deiodination by MPO and $\mathrm{H}_{2} \mathrm{O}_{2}$ but inhibits this reaction when $\mathrm{MPO}$ is replaced by lactoperoxidase or horseradish peroxidase.

Intact human leukocytes, in the resting state, degrade $T_{4}$ and $T_{3}$ slowly; degradation, however, is increased markedly during phagocytosis of preopsonized particles. Serum inhibits this reaction. $T_{3}$ can be detected as a minor product of $T_{4}$ degradation. Proteolytic digestion of the reaction products increases the recovery of monoiodotyrosine. The fixation of iodine in the cytoplasm of leukocytes which contain ingested bacteria was detected radioautographically. Chronic granulomatous disease leukocytes, which are deficient in $\mathrm{H}_{2} \mathrm{O}_{2}$ formation, degrade $T_{4}$ and $T_{3}$ poorly during phagocytosis. MPO-deficient leukocytes degrade the thyroid hormones at a slower rate than do normal leukocytes although considerable degradation is still observed. Azide, cyanide, ascorbic acid, and propylthiouracil which inhibit certain peroxidasecatalyzed reactions inhibit degradation by normal leukocytes; however, inhibition is incomplete. Formation of iodinated origin material is inhibited to a greater degree by azide, cyanide, and propylthiouracil than is deiodination. Methimazole inhibits the formation of iodinated origin material by both normal and MPO-deficient leuko-

These studies were presented in part at the 64th Annual Meeting of The American Society for Clinical Investigation (24).

Received for publication 25 July 1972 and in revised form 12 September 1972. cytes. However, deiodination by normal leukocytes is stimulated and that of MPO-deficient leukocytes is unaffected by methimazole. Hypoxia inhibits the degradation of $T_{4}$ and $T_{3}$ by untreated normal or MPO-deficient leukocytes and by normal leukocytes treated with azide or methimazole.

These data suggest that both MPO-dependent and MPO-independent systems are involved in the degradation of $T_{4}$ and $T_{3}$ by phagocytosing leukocytes. The role of leukocytic degradation of $T_{4}$ and $T_{3}$ in thyroid hormone economy and in leukocytic microbicidal activity is considered.

\section{INTRODUCTION}

The neutrophil peroxidase, myeloperoxidase (MPO), has potent antimicrobial activity against bacteria (1-5), fungi $(6,7)$, viruses (8), and mycoplasma (9) when combined with $\mathrm{H}_{2} \mathrm{O}_{2}$ and an oxidizable cofactor such as iodide, bromide, chloride, or thiocyanate ions. This system may be operative in the intact cell. MPO is present in the lysosomal granules of the neutrophil in exceptionally high concentration (10-13) and its release into the phagocytic vacuole has been demonstrated by electron microscopy $(7,14) . \mathrm{H}_{2} \mathrm{O}_{2}$ is formed by leukocytic metabolism during the respiratory burst associated with phagocytosis (15). $\mathrm{H}_{2} \mathrm{O}_{2}$ also is formed by certain microorganisms, namely the streptococci, pneumococci and lactobacilli, and the $\mathrm{H}_{2} \mathrm{O}_{2}$ so formed may contribute significantly to the microbicidal activity of the

1 Abbreviations used in this paper: $\mathrm{BEA}$, butanol: ethanol: $0.5 \mathrm{~N} \mathrm{NH}_{4} \mathrm{OH}, 5: 1: 2 ; \mathrm{BuAc}$, butanol saturated with $2 \mathrm{~N}$ acetic acid; CGD, chronic granulomatous disease; DIT, diiodotyrosine; HRP, horseradish peroxidase; $\mathrm{KRP}, \mathrm{Ca}^{++}$. free Krebs Ringer phosphate buffer $\mathrm{pH} 7.4$; LPO, lactoperoxidase ; MIT, monoiodotyrosine ; MPO, myeloperoxidase ; NBT, nitroblue tetrazolium; PMN, polymorphonuclear leukocyte; TA, tertiary amyl alcohol saturated with $2 \mathrm{~N}$ $\mathrm{NH}_{4} \mathrm{OH} ; \mathrm{T}_{3}$, triiodothyronine; $\mathrm{T}_{4}$, thyroxine. 
cell under certain conditions $(16,17)$. The concentration of chloride in the leukocyte is considerably greater than that which is required as a cofactor in the isolated MPO-mediated antimicrobial system $(5,18)$. Although iodide is much more effective than chloride on a molar basis in the isolated system (5), its concentration in extracellular fluid is very low, and it is not clear whether sufficient iodide enters the cell from this source to produce a significant microbicidal effect. The human leukocyte-to-medium iodide ratio was 4.2 under the conditions reported by Stolc (19) suggesting some concentration of iodide by leukocytes. Klebanoff and Hamon, however, could not detect iodide concentration by isolated resting human leukocytes under their experimental conditions (20).

Thyroxine $\left(T_{4}\right)$ or triiodothyronine $\left(T_{3}\right)$ can replace iodide as the cofactor in the isolated MPO-mediated antimicrobial system (3) presumably due, in part, to the deiodination of the thyroid hormones by $\mathrm{MPO}$ and $\mathrm{H}_{2} \mathrm{O}_{2}$ $(21,22)$ and the utilization of the released iodide in the microbicidal system. This raises the possibility that a similar reaction might occur in the intact leukocyte. The degradation of the thyroid hormones by phagocytosing leukocytes and the possible involvement of MPO and $\mathrm{H}_{2} \mathrm{O}_{2}$ in this reaction were therefore investigated. Reports dealing with this subject have recently appeared elsewhere (20. 23-25).

\section{METHODS}

Source of leukocytes. Blood was obtained from healthy adult volunteers, from six patients with chronic granulomatous disease (CGD) and from one patient with hereditary MPO-deficiency. The diagnosis of CGD was established in each patient by decreased leukocytic staphylocidal activity and nitroblue tetrazolium (NBT) reduction, and in all but two patients (D. G. and B. B.) by decreased iodination, glucose $\mathrm{C}-1$ oxidation, and formate oxidation. The CGD patients consisted of two female sibiings, Ke. IV. and Ki. W., ages 7 and 15, two male siblings, D. C. and R. C., ages 16 and 17 , and two other unrelated male patients, D. G. and B. B., ages 2 and 6 . The patient with hereditary MPO-deficiency was described in detail by Lehrer and Cline (26).

Preparation of leukocytes. In all cases, venous blood was collected locally in syringes moistened with heparin (Invenex, Division of the Mogul Corp. (Ohio), San Francisco, Calif., 1000 u.s.p. units per $\mathrm{ml}$ ) and isolation of the leukocytes was initiated within $30 \mathrm{~min}$ of collection using the method previously described (27). A leukocyte count and chamber differential were performed before the last wash, and a stock solution was prepared by suspending the cells in $\mathrm{Ca}^{++}$-free Krebs Ringer phosphate buffer pH 7.4 (KRP) to a final concentration of $5 \times 10^{7}$ polymorphonuclear leukocytes (PMNs) per ml.

Preparation of particles. Zymosan (Mann Research Labs, New York) was suspended in water to a final concentration of $10 \mathrm{mg} / \mathrm{ml}$ and homogenized for $1 \mathrm{~min}$ with a PotterElvehjem Teflon and glass homogenizer. The suspension $(1.0 \mathrm{ml})$ was centrifuged at $1600 \mathrm{~g}$ for $1 \mathrm{~min}$, the supernatant discarded, and the pellet suspended in $1.0 \mathrm{ml}$ of serum obtained from a donor with $\mathrm{AB}$ blood group. The suspension was incubated for $15 \mathrm{~min}$ at $37^{\circ} \mathrm{C}$. The zymosan was collected by centrifugation and washed three times with water and suspended to the original volume with water. This preparation is referred to as "preopsonized zymosan."

Lactobacillus acidophilus (ATCC No. 4357) was grown overnight in Lactobacillus-selective broth (Baltimore Biological Laboratory, Baltimore, Md.). The bacteria were washed twice in water, heated at $100^{\circ} \mathrm{C}$ for $30 \mathrm{~min}$, and opsonized by suspension in $\mathrm{AB}$ serum as described above. The organisms were washed twice with water and suspended in water to the required optical density at $540 \mathrm{~nm}$, determined with a Coleman Junior spectrophotometer (Coleman Instruments Div., The Perkin-Elmer Corp., Norwalk, Conn.).

Source of peroxidase. Canine MPO was prepared in highly purified form (i.e., to the end of step 6) from pyometral pus by the method of Agner (28). Human MPO was kindly supplied by Dr. J. Schultz. Lactoperoxidase (LPO) was prepared from bovine milk by the method of Morrison and Hultquist (29). Horseradish peroxidase (HRP, electrophoretically purified, $\mathrm{RZ}=2.9-3.0$ ) was obtained from Worthington Biochemical Corp., Freehold, N. J. Peroxidase activity was determined by the $o$-dianisidine method (30). $1 \mathrm{U}$ of activity is that causing an increase in absorbancy of $0.001 / \mathrm{min}$ at $460 \mathrm{~nm}$ in a Cary M15 spectrophotometer.

Labcled compounds. $\quad\left[{ }^{125} \mathrm{I}\right] \mathrm{T}_{4}$ and $\left[{ }^{125} \mathrm{I}\right] \mathrm{T}_{3}(55-85 \mu \mathrm{Ci} / \mu \mathrm{g})$ in $50 \%$ propylene glycol (Abbott Laboratories, North Chicago, Ill.) were diluted to a final concentration of $100 \mu \mathrm{Ci} / \mathrm{ml}$ in physiological saline containing $0.2 \%$ human serum albumin (rormal serum albumin (human) salt-poor, Cutter Laboratories, Berkeley, Calif.). Albumin was employed to stabilize the hormones and to prevent binding to glass. The stock solution was filtered through a membrane filter with an average pore size of $0.45 \mu \mathrm{m}$ (B-6; Bact T-Flex, $24 \mathrm{~mm}$ dianeter, Schleicher \& Schuell Inc., Keene, N. H.) just prior to use.

Measurement of hormone degradation. The components of the reaction mixture are indicated in the legends and text. The propylene glycol concentration of the final reaction mixture was less than $1 \%$ and the albumin concentration was $0.01 \%$. These components were added with the labeled hormones (see above). Incubations were conducted at $37^{\circ} \mathrm{C}$ in liquid scintillation vials siliconized with Siliclad (ClayAdams, Inc., Parsippany, N. J.) in a water bath shaker (Eberbach Corp., Detroit, Mich.) oscillating 80 times a minute. Portions $(0.05 \mathrm{ml})$ were removed at intervals and added to $0.05 \mathrm{ml}$ of $25 \%$ human serum albumin containing $0.01 \mathrm{M}$ potassium iodide and $0.001 \mathrm{M}$ propylthiouracil. In the standard procedure, duplicate $25 \mu \mathrm{l}$ samples were applied, together with carrier iodide and iodoamino acids, to strips of Whatman no. 1 filter paper, and ascending chromatography was performed at room temperature in butanol saturated with $2 \mathrm{~N}$ acetic acid (BuAc) for 16-18 h. Autoradiography using Kodak No-Screen X-ray film usually demonstrated three major loci of radioactivity: (a) "origin material" at the origin; (b) "iodide" corresponding to the iodide carrier, visualized by staining with palladium chloride, and $(c)$ "iodothyronine" corresponding to the $T_{4}$ and $T_{3}$ carriers, which were stained with ninhydrin (the BuAc solvent system does not separate $T_{4}$ from $T_{3}$ ). The strips were cut into three segments corresponding to these zones as shown in Fig. 1, and the segments were counted in a Packard AutoGamma Well Scintillation Counter. The per cent of total radioactivity converted to origin material and iodide were routinely used as an index of hormone degradation. Correction was made for the small amount (less than $4 \%$ ) of 


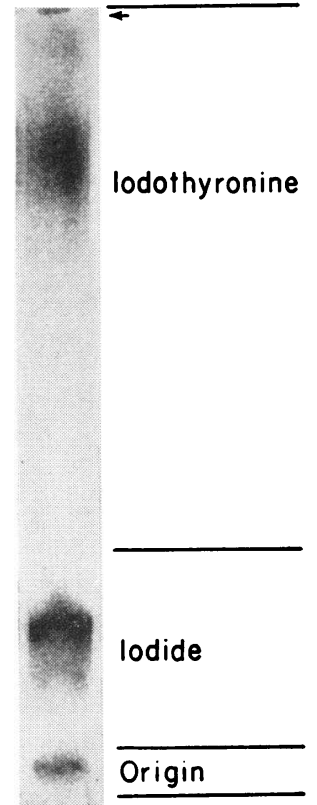

FIGURE 1 Autoradiograph of chromatography strip showing division for counting. Solvent-BuAc; arrow indicates solvent front. $T_{4}$ incubated with intact leukocytes and preopsonized zymosan.

labeled origin material or iodide present following incubation in buffer alone.

In some experiments, degradation products were further characterized by the following separative techniques: (a) Ascending paper chromatography in butanol: ethanol: $0.5 \mathrm{~N}$ $\mathrm{NH}_{4} \mathrm{OH}, 5: 1: 2$ (BEA) for 16-18 h, either as the sole solvent system or as the second dimension following chromatography in BuAc; (b) Descending paper chromatography in tertiary amyl alcohol saturated with $2 \mathrm{~N} \mathrm{NH}_{4} \mathrm{OH}$ (TA) for $24 \mathrm{~h}$; (c) Electrophoresis at a constant current of $8 \mathrm{~mA}$ on $32-\mathrm{cm}$ wide sheets of Whatman no. 3 filter paper in Trismaleate buffer, $\mathrm{pH} 8.6$, for $3 \mathrm{~h}$.

In some instances products of hormone degradation were subjected to proteolytic digestion. Portions of reaction mixtures were diluted with 2 vol of a buffer containing $40 \mathrm{mM}$ Tris, $108 \mathrm{mM} \mathrm{NaCl}$, and $20 \mathrm{mM}$ methimazole; pancreatin was added to a final concentration of $1 \%$; and the $\mathrm{pH}$ was adjusted to 8.5 with $1 \mathrm{~N} \mathrm{NaOH}$. Following incubation at $37^{\circ} \mathrm{C}$ overnight, chromatography in BuAc was performed as described above. The paper strips were cut into segments corresponding to ninhydrin-stained carrier monoiodotyrosine (MIT), diiodotyrosine (DIT), $T_{4}$ and $T_{3}$, and the segments were counted in a well scintillation counter.

Autoradiographic localization of iodine in leukocytes. Into $12 \times 75 \mathrm{~mm}$ siliconized test tubes were added $1 \times 10^{7} \mathrm{PMNs}$, ${ }^{5-10} \mu \mathrm{Ci}$ of $\left[{ }^{125} \mathrm{I}\right] \mathrm{T}_{4}$ or $\left.{ }^{[225} \mathrm{I}\right] \mathrm{T}_{3}, 1 \mu \mathrm{mol}$ of glucose, $1 \times 10^{8}$ Lactobacillus acidophilus (heat-killed and preopsonized) where indicated, and KRP to a final volume of $0.5 \mathrm{ml}$. The tubes were incubated at $37^{\circ} \mathrm{C}$ in a water bath shaker oscillating 80 times per minute. Cover slip smears, prepared at the time periods indicated, were fixed for $4 \mathrm{~min}$ in absolute methanol, washed for $1 \mathrm{~h}$ in water and autoradiograms were prepared as previously described (3).

Production of hypoxia. The leukocyte suspension was placed in the side arm and the remaining components in the main compartment of siliconized $7 \mathrm{ml}$ Warburg flasks. After gassing for 20 min with prepurified nitrogen (Ohio Medical Products, Madison, Wisc.) the leukocytes were tipped into the main compartment and the incubation continued for 30 min. Portions $(0.05 \mathrm{ml})$ were removed and the components separated by chromatography as described above.

\section{RESULTS}

\section{Degradation of thyroid hormones by MPO and $\mathrm{H}_{2} \mathrm{O}_{2}$}

Table I demonstrates the marked conversion of the labeled iodine of $\left[{ }^{125} \mathrm{I}\right] \mathrm{T}_{4}$ and $\left[{ }^{225} \mathrm{I}\right] \mathrm{T}_{3}$ to inorganic iodide and to origin material during a $30 \mathrm{~min}$ incubation with MPO and $\mathrm{H}_{2} \mathrm{O}_{2}$ in phosphate buffer $\mathrm{pH}$ 7.0. Little or no conversion occurred when the hormones were exposed to MPO or $\mathrm{H}_{2} \mathrm{O}_{2}$ alone or when heat-inactivated MPO was employed. The effect of $\mathrm{pH}$ on hormone degradation is shown in Fig. 2. The release of inorganic iodide from $\mathrm{T}_{4}$ and $\mathrm{T}_{\mathbf{3}}$ decreased as the $\mathrm{pH}$ was lowered from 7.0 to 5.0. The absolute amount of labeled origin material formed from $T$, increased over this range whereas a maximum was observed at $\mathrm{pH} 6.5$ with $\mathrm{T}_{\mathrm{s}}$. The proportion of the total released iodine found in the origin material at $\mathrm{pH} 5.0$ was approximately 0.5 with both hormones and was considerably greater than the proportion found at $\mathrm{pH}$ 7.0.

Deiodination and conversion of hormonal iodine to origin material by $\mathrm{MPO}$ and $\mathrm{H}_{2} \mathrm{O}_{2}$ were strongly inhibited by azide, cyanide, ascorbic acid, and propylthiouracil (Fig. 3). Methimazole, however, while inhibiting the formation of iodinated origin material, did not inhibit deiodination. Indeed, the recovery of inorganic iodide was increased by methimazole. Stimulation of MPO-catalyzed deiodination by methimazole was more striking when the MPO concentration was decreased to a

TABLE I

Degradation of Thyroid Hormones by $\mathrm{MPO}$ and $\mathrm{H}_{2} \mathrm{O}_{2}{ }^{*}$

\begin{tabular}{lcrrrr}
\hline & \multicolumn{4}{c}{ Percent conversion } \\
\cline { 2 - 5 } & \multicolumn{2}{c}{$\mathrm{T}_{4}$} & & \multicolumn{2}{c}{$T_{3}$} \\
\cline { 2 - 6 } \cline { 5 - 6 } Supplements & $\begin{array}{c}\text { Origin } \\
\text { material }\end{array}$ & Iodide & $\begin{array}{c}\text { Origin } \\
\text { material }\end{array}$ & Iodide \\
\hline $\mathrm{MPO}$ & 0 & 0.9 & & 0.8 & 1.2 \\
$\mathrm{H}_{2} \mathrm{O}_{2}$ & 0.3 & 0.1 & & 0.1 & 0.2 \\
$\mathrm{MPO}+\mathrm{H}_{2} \mathrm{O}_{2}$ & 10.5 & 55.4 & 13.4 & 38.9 \\
$\mathrm{MPO}$ (heated) $+\mathrm{H}_{2} \mathrm{O}_{2}$ & 0.5 & 0.8 & 0.4 & 0.2 \\
\hline
\end{tabular}

* The reaction mixture contained $30 \mu \mathrm{mol}$ of phosphate buffer $\mathrm{pH} 7.0$, either $\left[{ }^{125} \mathrm{I}\right] \mathrm{T}_{4}(2.5 \mu \mathrm{Ci} ; \sim 0.02 \mu \mathrm{g})$ or $\left.{ }^{125} \mathrm{I}\right] \mathrm{T}_{3}(2.5$ $\mu \mathrm{Ci} ; \sim 0.02 \mu \mathrm{g})$, water to a final volume of $0.5 \mathrm{ml}$ and the supplements indicated as follows: $\mathrm{MPO}, 150 \mathrm{U} ; \mathrm{H}_{2} \mathrm{O}_{2}, 0.05$ $\mu \mathrm{mol}$. The MPO was heated at $100^{\circ} \mathrm{C}$ for $10 \mathrm{~min}$ where indicated. Incubation $30 \mathrm{~min}$. The results are the mean of three experiments, each with duplicate values. 
level where control deiodination (i.e., deiodination in the absence of methimazole) was very low (Fig. 4). Methimazole-dependent deiodination was abolished by the deletion of either MPO or $\mathrm{H}_{2} \mathrm{O}_{2}$ (Fig. 4) or by heat inactivation of MPO (not shown). Paradoxically, methimazole increased the formation of iodinated origin material under the conditions employed in Fig. 4. Further analyses were performed to assure that the major product formed on incubation of labeled $T_{4}$ and $T_{2}$ with MPO, $\mathrm{H}_{2} \mathrm{O}_{2}$, and methimazole, under the conditions employed in Fig. 4, was iodide. The products formed were separated by $(a)$ two dimensional ascending chromatography, using BuAc followed by BEA; $(b)$ paper electrophoresis

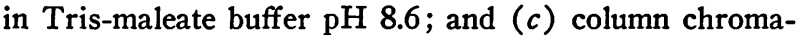
tography on Sephadex G25. The major product behaved like iodide in all systems. Methimazole stimulated deiodination by both canine and human MPO (Table II); however, the deiodination of the thyroid hormones by LPO or by $\mathrm{HRP}$ and $\mathrm{H}_{2} \mathrm{O}_{2}$ was not stimulated but rather was inhibited by methimazole. Table II also demonstrates that when the peroxidases are standardized on the basis of the 0 -dianisidine assay, their efficiency for thyroid hormone degradation at $\mathrm{pH} 7.0$ is in the order LPO > MPO > HRP.

\section{Degradation of thyroid hormones by intact} leukocytes

Fig. 5 demonstrates the degradation of $T_{4}$ and $T_{3}$ by phagocytosing human leukocytes. No conversion of the labeled iodine to inorganic iodide or to origin material was observed when $T_{4}$ and $T_{3}$ were incubated with particles alone, and relatively little conversion occurred

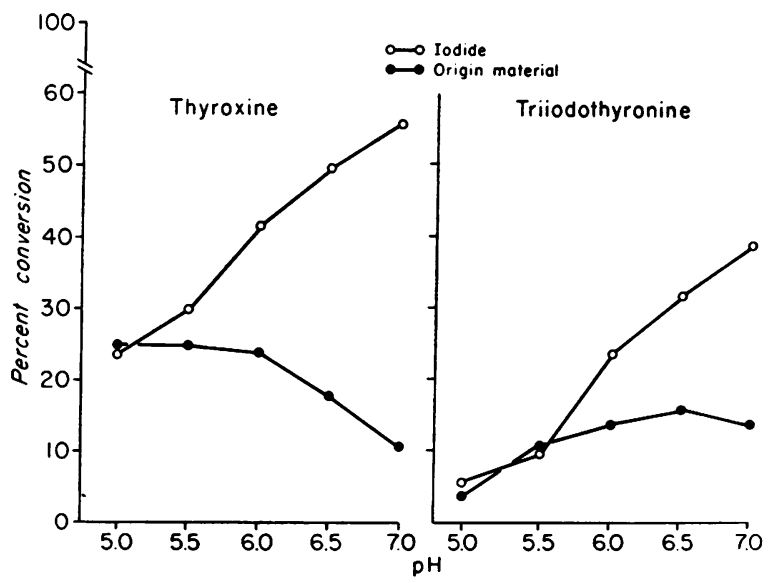

FIgURE 2 Effect of $\mathrm{pH}$ on the degradation of the thyroid hormones by MPO and $\mathrm{H}_{2} \mathrm{O}_{2}$. The procedure was as described in Table I (MPO $\left.+\mathrm{H}_{2} \mathrm{O}_{2}\right)$ except that the buffer was varied as indicated. Phosphate buffer was employed at $\mathrm{pH} 7.0,6.5$, and 6.0 and lactate buffer at $\mathrm{pH} 6.0,5.5$, and 5.0. The effects at $\mathrm{pH} 6.0$ were similar with phosphate or lactate buffer and the results were pooled.

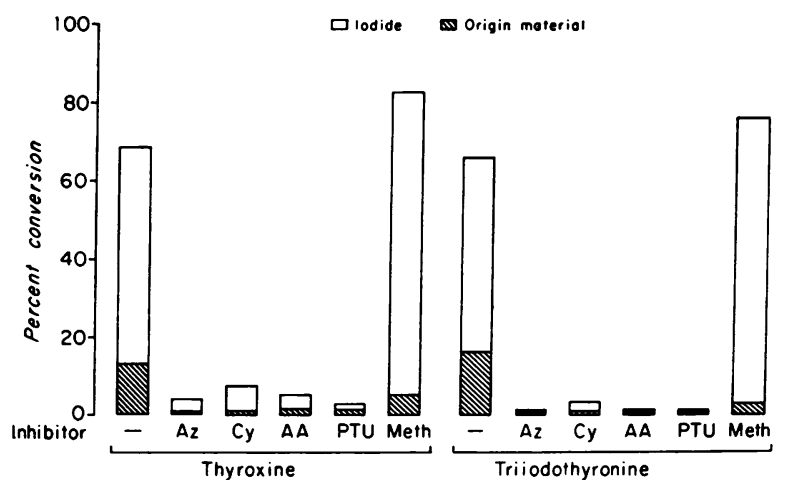

FIGURE 3 Effect of various agents on the degradation of the thyroid hormones by $\mathrm{MPO}$ and $\mathrm{H}_{2} \mathrm{O}_{2}$. The procedure was as described in Table I (MPO $+\mathrm{H}_{2} \mathrm{O}_{2}$ ) except that 0.5 $\mu \mathrm{mol}$ of either azide $(\mathrm{Az})$, cyanide $(\mathrm{Cy})$, ascorbic acid (AA), propylthiouracil (PTU), or methiniazole (Meth) were added where indicated.

when incubation was with leukocytes alone. However, when the two were combined, rapid deiodination and transfer of iodine to origin material were observed. Preopsonized zymosan was employed in Fig. 5 as the particle; similar results were obtained with preopsonized L. acidophilus. $\mathrm{Ca}^{++}$-free $\mathrm{KRP}$ was employed in the incubation mixture; the addition of $\mathrm{Ca}^{++}$to a final concentration of $0.5 \mathrm{mM}$ did not alter degradation by resting or phagocytosing leukocytes under the conditions employed.

The particles were preopsonized by incubation with serum at $37^{\circ} \mathrm{C}$ for $15 \mathrm{~min}$ and were then washed free

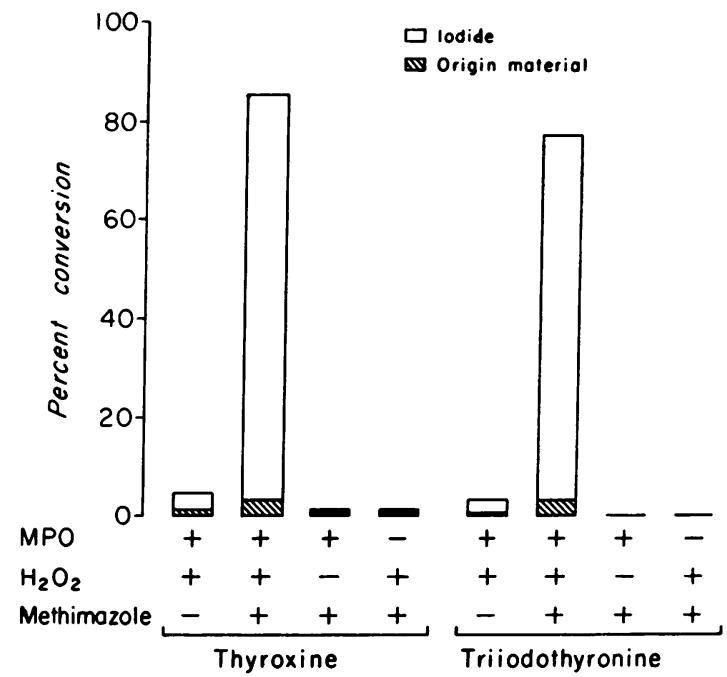

FIGURE 4 Effect of methimazole on the degradation of the thyroid hormones by MPO and $\mathrm{H}_{2} \mathrm{O}_{2}$. The procedure was as described in Table I ( $\left.\mathrm{MPO}+\mathrm{H}_{2} \mathrm{O}_{2}\right)$ except that 15 units of MPO were employed and methimazole $(0.5 \mu \mathrm{mol})$ was added where indicated. 
TABLE II

Effect of Methimazole on the Degradation of $T_{4}$ and $T_{3}$ by Various Peroxidases*

\begin{tabular}{|c|c|c|c|c|c|}
\hline \multirow[b]{3}{*}{ Peroxidase } & \multirow[b]{3}{*}{$\begin{array}{l}\text { Peroxidase } \\
\text { activity }\end{array}$} & \multicolumn{4}{|c|}{$\begin{array}{l}\text { Percent conver sion to iodide } \\
\quad+\text { origin material }\end{array}$} \\
\hline & & \multicolumn{2}{|c|}{$T_{4}$} & \multicolumn{2}{|c|}{$\mathrm{T}_{3}$} \\
\hline & & $\begin{array}{l}\text {-methi- } \\
\text { mazole }\end{array}$ & $\begin{array}{l}\text { +methi- } \\
\text { mazole }\end{array}$ & $\begin{array}{l}\text {-methi- } \\
\text { mazole }\end{array}$ & $\begin{array}{l}\text { +methi- } \\
\text { mazole }\end{array}$ \\
\hline & $U$ & & & & \\
\hline MPO (canine) & 15 & 2.1 & 80.7 & 2.2 & 70.0 \\
\hline MPO (human) & 15 & 4.7 & 79.5 & 3.0 & 69.1 \\
\hline LPO (bovine) & 15 & 67.7 & 1.0 & 21.6 & 0.4 \\
\hline HRP & 150 & 34.9 & 3.2 & 10.2 & 2.1 \\
\hline
\end{tabular}

* The procedure was as described in Table I (MPO $\left.+\mathrm{H}_{2} \mathrm{O}_{2}\right)$ except that the type and amount of peroxidase were varied as indicated. The results are the mean of two experiments each with duplicate values.

of unattached serum components. This was necessary since serum inhibited the degradation of $T_{4}$ and $T_{3}$ by phagocytosing leukocytes (Fig. 6). This is due presumably to the binding of the thyroid hormones by serum proteins. Serum was a more effective inhibitor of $T_{4}$ degradation than of $\mathrm{T}_{3}$ degradation as would be expected from the greater affinity of thyroxine for plasma protein binding sites. The presence of a small amount of albumin $(0.01 \%)$ in the reaction mixture (see Methods) suppressed degradation by resting leukocytes slightly (total degradation in $60 \mathrm{~min}: \mathrm{T}_{4}, 6.4 \%$ without albumin, $3.5 \%$ with albumin; $\mathrm{T}_{3}, 5.0 \%$ without albumin, $4.2 \%$ with

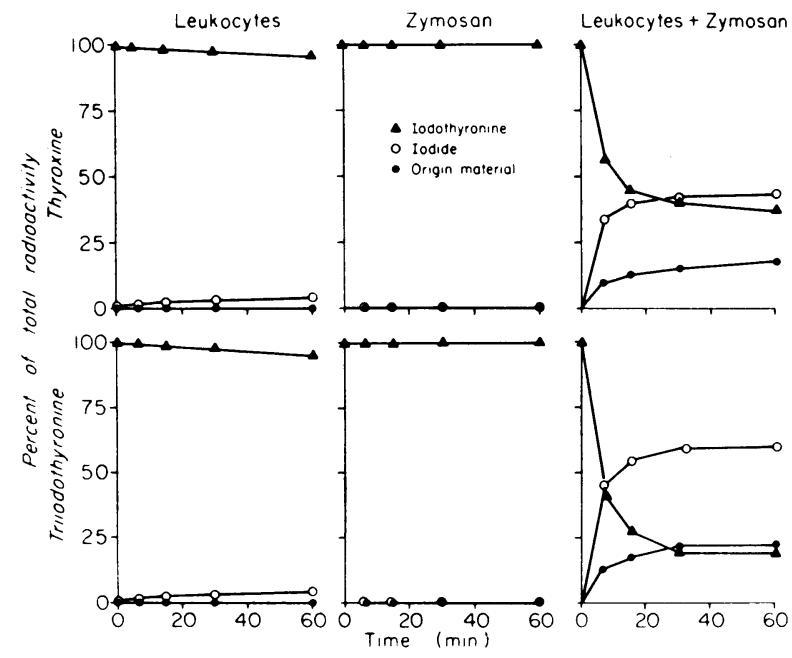

FigUre 5 Degradation of $T_{4}$ and $T_{3}$ by phagocytosing leukocytes. The reaction mixture contained $0.3 \mathrm{ml}$ of KRP, 1 $\mu \mathrm{mol}$ of glucose, either $\left[{ }^{125} \mathrm{I}\right] \mathrm{T}_{4}$ or $\left[{ }^{125} \mathrm{I}\right] \mathrm{T}_{3}(2.5 \mu \mathrm{Ci} ; \sim 0.02$ $\mu \mathrm{g}$ ), water to a final volume of $0.5 \mathrm{ml}$ and, where indicated, $1 \times 10^{7} \mathrm{PMNs}$ and $0.5 \mathrm{mg}$ of preopsonized zymosan. albumin [average of three experiments]) but did not suppress degradation by phagocytosing leukocytes $\left(\mathrm{T}_{4}\right.$, $59.2 \%$ without albumin, $63.3 \%$ with albumin; $\mathrm{T}_{3}$, $71.7 \%$ without albumin, $82.9 \%$ with albumin [average of three experiments]).

Several chromatographic systems were employed to identify metabolites of $T_{4}$ and $T_{3}$ other than iodide and origin material. $T_{3}$, one potential product of $T_{4}$ breakdown, could not be identified with certainty in BEA or TA chromatograms in eight experiments employing the standard incubation conditions (see Fig. 5). Since rapid degradation of $\mathrm{T}_{3}$ could limit its recovery under these conditions, two experiments were performed in which a high concentration of stable $T_{3}, 10^{-4} \mathrm{M}$, was employed to decrease the percent $T_{3}$ degraded. In these experiments, a spot congruent with the $\mathrm{T}_{3}$ carrier was identified by autoradiography of TA chromatograms, and comprised about $2 \%$ of the total radioactivity. Under these conditions, $10^{-4} \mathrm{M} \mathrm{T}_{3}$ decreased the total degradation of both labeled $\mathrm{T}_{4}$ and $\mathrm{T}_{3}$ by phagocytosing leukocytes to about $20-30 \%$ as $\operatorname{did} 10^{-4} \mathrm{M} \mathrm{T}$. This is due presumably to competition between stable and labeled hormones for the deiodinating systems. An unknown compound, or group of compounds, was frequently seen beyond the iodothyronine zones in all three systems (solvent front material), and comprised $4-7 \%$ of the total radioactivity. Also, unidentified radioactive bands were observed between the

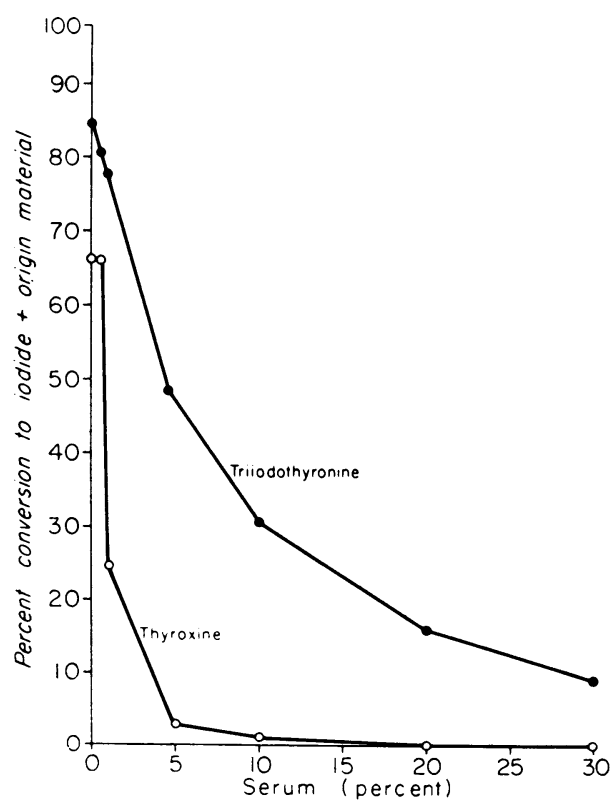

FIGURE 6 Effect of serum on thyroid hormone degradation by phagocytosing leukocytes. The reaction mixture was as described in Fig. 5 (leukocytes + zymosan) except that $\mathrm{AB}$ serum was added to the concentrations indicated. 


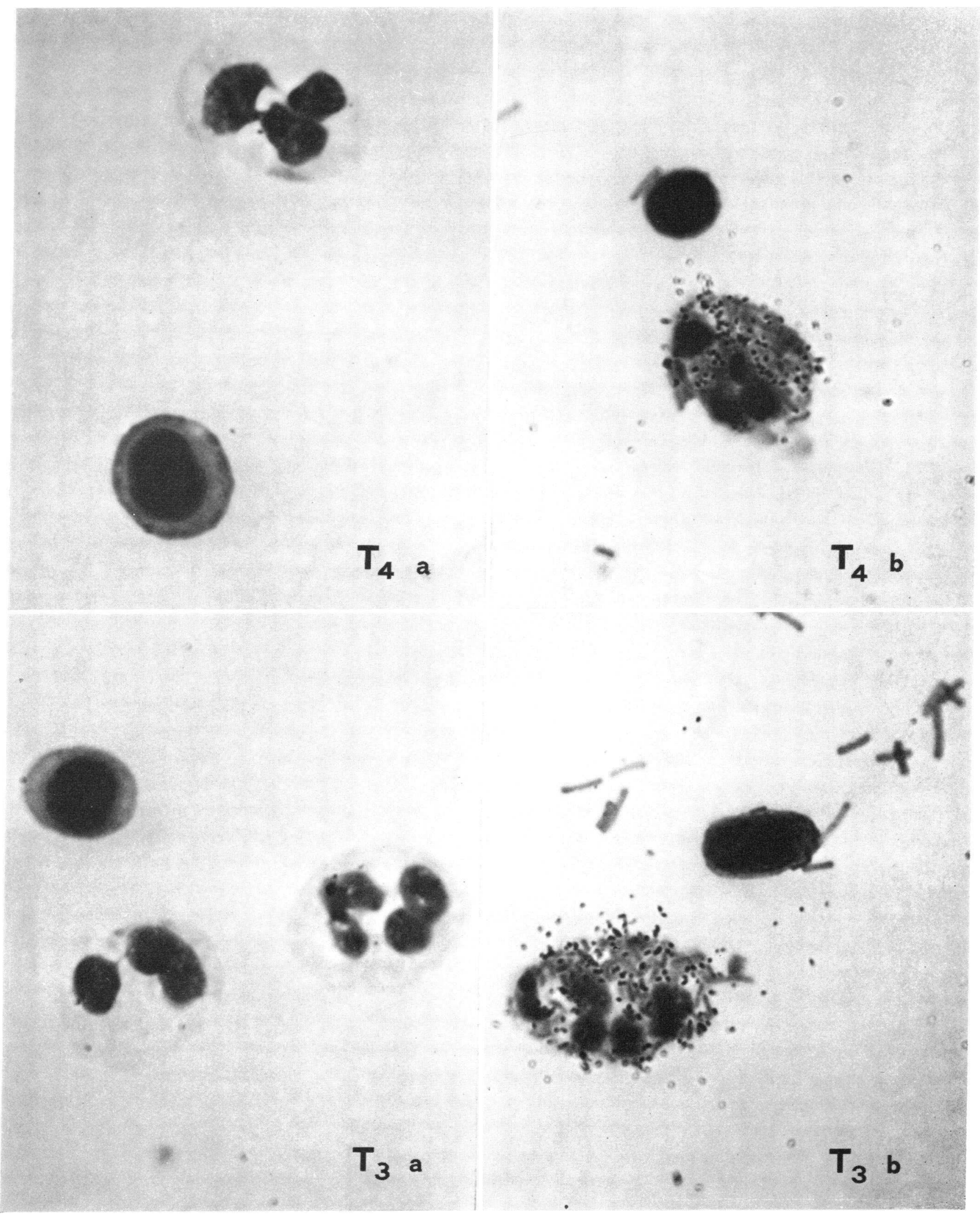

FIGURE 7 Autoradiograms demonstrating the fixation of the labeled iodine of $T_{4}$ and $T_{3}$ by resting $(a)$ and phagocytosing $(b)$ leukocytes. 


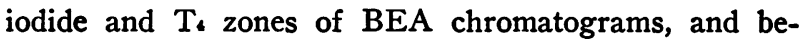
tween the iodotyrosine and iodide zones of TA chromatograms.

When digestion with pancreatin was performed after incubating either $T_{4}$ or $T_{3}$ with phagocytosing leukocytes, about $40 \%$ of the origin material was undigested; about $30 \%$ was converted to MIT and less than $8 \%$ to DIT. The remainder was recovered as inorganic iodide.

When iodide is employed as the cofactor in the isolated MPO-mediated antimicrobial system, iodination of the microorganisms occurs (3). Iodination also occurs in the intact leukocyte following the ingestion of an appropriate particle $(3,27)$ and fixed iodide can be localized, in part, in the phagocytic vacuole in association with the ingested particles $(7,31)$. Fig. 7 demonstrates the fixation of hormonal radioiodine in the cytoplasm of neutrophils which contain ingested bacteria. Under these conditions, no iodine remains bound to extracellular bacteria or to leukocytes which do not contain ingested organisms.

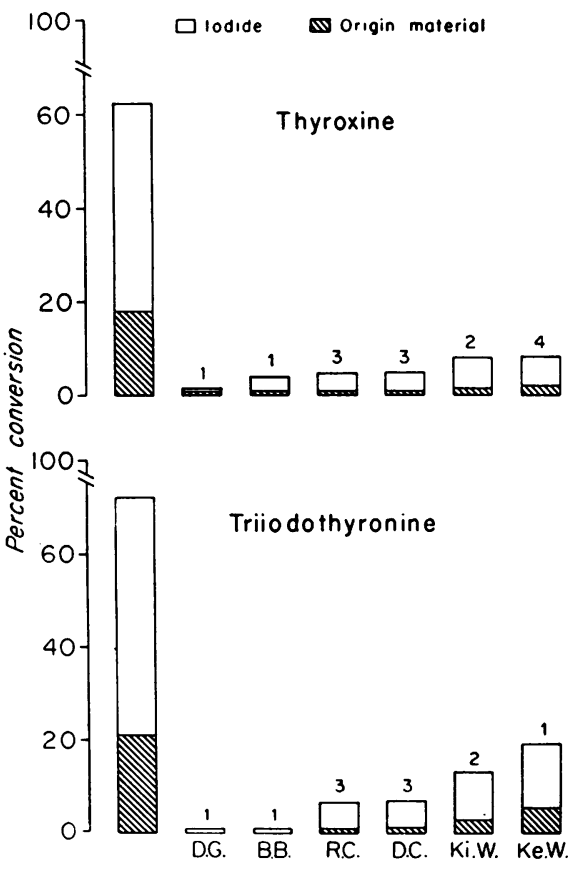

FIGURE 8 Thyroid hormone degradation by leukocytes of patients with chronic granulomatous disease (CGD). The reaction mixture was as described in Fig. 5 (leukocytes + zymosan) except that leukocytes of six patients with CGD were employed where indicated. Incubation $30 \mathrm{~min}$. The number of separate experiments is indicated above each bar. A control with normal leukocytes was employed in each experiment and pooled results are shown in the left hand column.

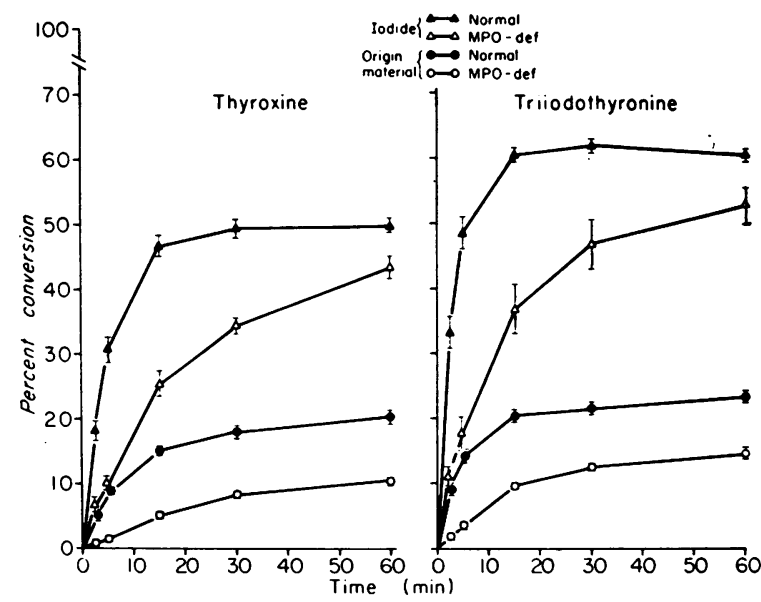

FIGURE 9 Thyroid hormone degradation by MPO-deficient leukocytes. The reaction mixture was as described in Fig. 5 (leukocytes + zymosan) except that leukocytes of a patient with hereditary MPO-deficiency were employed where indicated. The data on normal cells are the mean ISE of 20 experiments each on a different individual and the data on MPO-deficient leukocytes are the mean $\pm \mathrm{SE}$ of five experiments on one individual. The differences between MPOdeficient leukocytes and the paired normal (five experiments) are significant at all time periods $\left(P<0.01\right.$ except $\mathrm{T}_{4}, 60$ min, origin material, $P<0.02 ; \mathrm{T}_{3} 60 \mathrm{~min}$, iodide, $P<0.05$ ).

Role of MPO and $\mathrm{H}_{2} \mathrm{O}_{2}$ in the degradation of the thyroid hormones by phagocytosing leukocytes

The rapid degradation of the thyroid hormones by MPO and $\mathrm{H}_{2} \mathrm{O}_{2}$ and the presence of these substances in the phagocytic vacuole suggests that $\mathrm{MPO}$ and $\mathrm{H}_{2} \mathrm{O}_{2}$ may be involved in thyroid hormone degradation by phagocytosing leukocytes. This can be investigated through the use of leukocytes which are deficient in $\mathrm{H}_{2} \mathrm{O}_{2}$ or in MPO or by the use of inhibitors of peroxidase-catalyzed reactions.

Chronic granulomatous disease. Patients with CGD suffer from repeated and severe infections with Staphylococcus aureus and certain gram-negative pathogens due to a defect in leukocytic microbicidal activity (32). Among the metabolic abnormalities in CGD leukocytes is the essential absence of $\mathrm{H}_{2} \mathrm{O}_{2}$ formation following phagocytosis (33). Leukocytes from two female and four male patients with this condition degraded $T_{4}$ and $T_{3}$ poorly (Fig. 8). The most severe defect was seen in patients DG and BB who also were the most severely ill of the patients studied.

Hereditary MPO deficiency. Hereditary MPO deficiency is a rare condition in which MPO is absent from neutrophils and monocytes $(34,35,26)$. Patients with this condition have leukocytes with decreased fungicidal and bactericidal activity $(26,36,37)$. The bactericidal activity of these cells is characterized by a lag period following which death of the organisms is observed. 


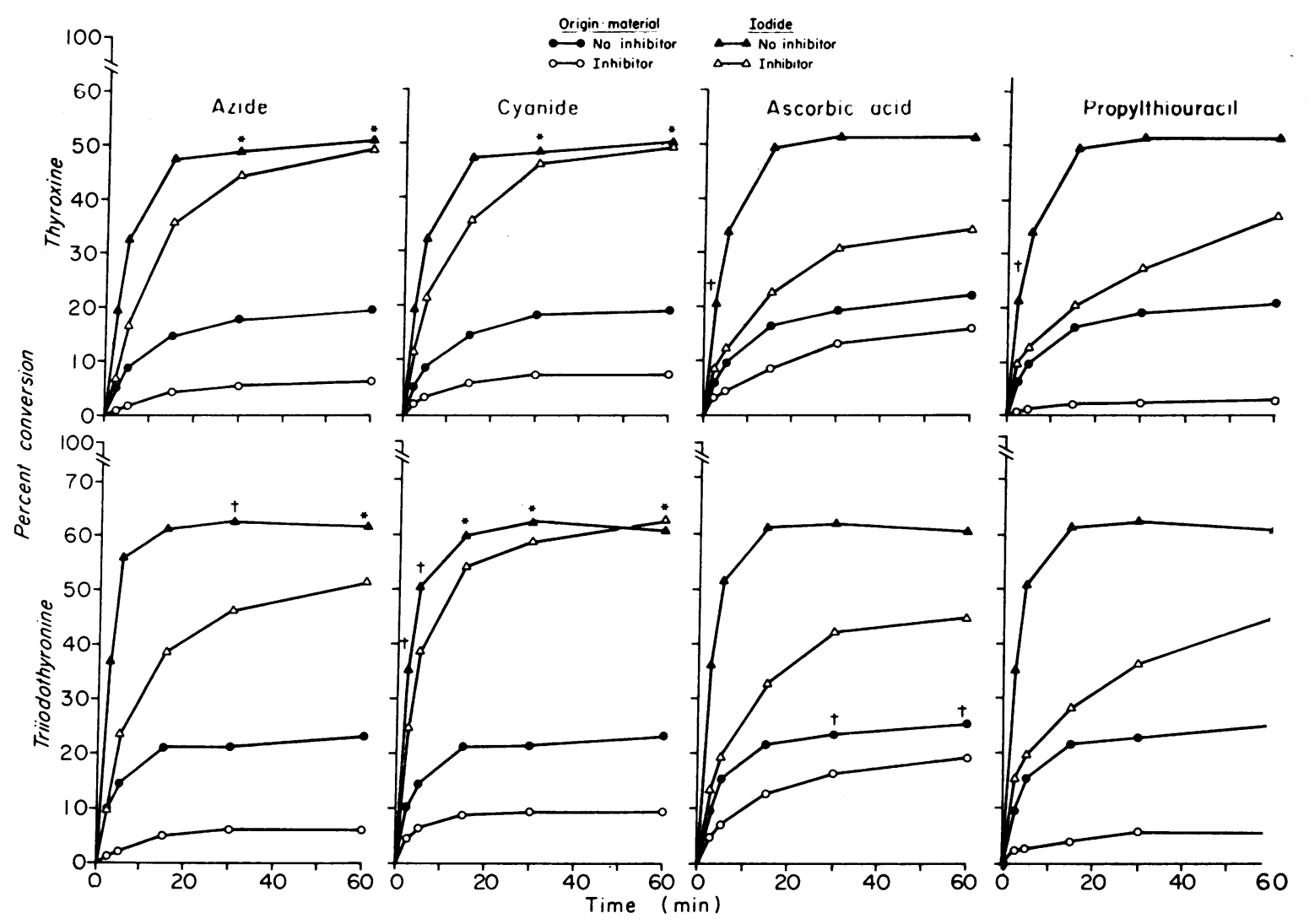

FIgURE 10 Effect of azide, cyanide, ascorbic acid, and propylthiouracil on thyroid hormone degradation by normal leukocytes. The reaction mixture was as described in Fig. 5 (leukocytes + zymosan) except that $0.5 \mu \mathrm{mol}$ of the inhibitors were added where indicated. The results shown are mean values from seven separate experiments (azide and cyanide), six experiments (ascorbic acid), or five experiments (propylthiouracil). The significance of the difference between inhibitor and control was assessed by the paired $t$ test (* not significant $P>0.05$; $\dagger P<0.05,>0.01$; remainder $P<0.01$ ).

Phagocytosing leukocytes from one patient with this condition degraded $T_{4}$ and $T_{3}$ at a slower rate than did normal leukocytes (Fig. 9). The formation of labeled origin material and inorganic iodide remained significantly depressed at all time periods. However, deiodination approached that of normal cells following $60 \mathrm{~min}$ of incubation.

Inhibitors of peroxidase catalyzed reactions. The effects of $1 \mathrm{mM}$ azide, cyanide, ascorbic acid, and propylthiouracil on the conversion of the labeled iodine of $\mathrm{T}_{4}$ and $T_{3}$ to origin material and iodide is shown in Fig. 10. All of the inhibitors decreased the formation of iodinated origin material throughout the $60 \mathrm{~min}$ incubation period. The inhibitory effect was in the order: propylthiouracil $>$ azide $>$ cyanide $>$ ascorbic acid. The release of inorganic iodide also was decreased by all of the inhibitors. However, the formation of origin material was inhibited to a greater degree than deiodination by all inhibitors except ascorbic acid. The release of inorganic iodide by inhibitor-treated cells eventually approached that of untreated cells. Indeed, inhibition of deiodination by azide and cyanide was significant only at the early time periods.

The effect of methimazole on the degradation of the thyroid hormones by phagocytosing normal and MPOdeficient leukocytes is shown in Fig. 11. The initial thyroid hormone concentration was increased to $10^{-4} \mathrm{M}$ in this experiment in order to depress the percent conversion in the absence of methimazole. The data illustrate a number of points: (a) Phagocytosing normal leukocytes have a very high capacity for the degradation of $T_{4}$ and $\mathrm{T}_{3}$. When the initial thyroid hormone concentration is increased to $10^{-4} \mathrm{M}$ (approx. $8000 \mu \mathrm{g} / 100 \mathrm{ml}$ ), approximately $30 \%$ of the labeled iodine can be recovered as origin material + iodide following a $30 \mathrm{~min}$ incubation with leukocytes and zymosan. Under these conditions, about $12 \mu \mathrm{g}$ of $\mathrm{T}_{4}$ or $\mathrm{T}_{3}$ were degraded by $10^{7} \mathrm{PMNs}$ in $30 \mathrm{~min}$; $(b)$ The decreased degradation of $\mathrm{T}_{4}$ and $\mathrm{T}_{3}$ 


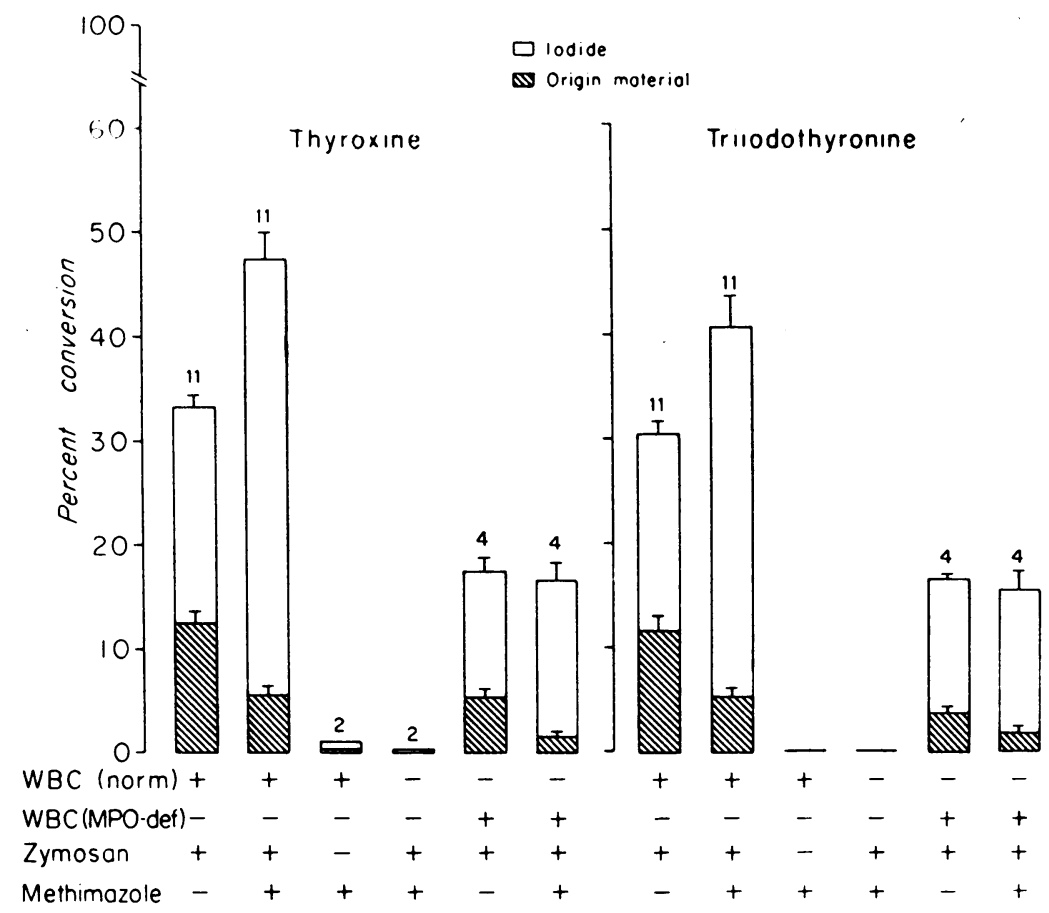

FIGLRE 11 Effect of methimazole on thyroid hormone degradation by normal and MPO-deficient leukocytes. The reaction mixture contained $0.3 \mathrm{ml}$ of KRP, $1 \mu \mathrm{mol}$ of glucose, either ${ }^{125} \mathrm{I}^{12} \mathrm{~T}_{4}$ or $\left[{ }^{125} \mathrm{I}\right] \mathrm{T}_{3}(2.5 \mu \mathrm{Ci}-0.05 \mu \mathrm{mol})$ water to a final volume of $0.5 \mathrm{ml}$ and where indicated $1 \times 10^{7}$ normal or MPO-deficient leukocytes, $0.5 \mathrm{mg}$ of preopsonized zymosan, and $0.5 \mu \mathrm{mol}$ of methimazole. Incubation $30 \mathrm{~min}$. The number of separate experiments is indicated above each bar; SEs are shown.

by MPO-deficient leukocytes previously observed when low levels of thyroid hormone were employed (Fig. 9) is also observed when the $T_{4}$ and $T_{3}$ concentration is increased to $10^{-4} \mathrm{M}(P<0.05$ for origin material, iodide or

TABLE III Effect of Hypoxia*

\begin{tabular}{|c|c|c|c|c|}
\hline \multirow[b]{3}{*}{ Reaction mixture } & \multicolumn{4}{|c|}{ Percent decrease in conversion } \\
\hline & \multicolumn{2}{|c|}{ T، } & \multicolumn{2}{|c|}{$T_{2}$} \\
\hline & Origin & Iodide & Origin & Iodide \\
\hline Standard (3) & 94.1 & 89.0 & 92.8 & 80.9 \\
\hline Standard + azide $(2)$ & 86.6 & 83.7 & 81.3 & 83.2 \\
\hline Standard + methimazole $(2)$ & 92.8 & 79.0 & 80.5 & 79.1 \\
\hline MPO-deficient (1) & 82.9 & 87.1 & 87.8 & 88.1 \\
\hline
\end{tabular}

* The standard reaction mixture was as described in Fig. 5 (leukocytes + zymosan). MPO-deficient leukocytes, azide, or methimazole $(0.5 \mu \mathrm{mol})$ were employed as indicated. Paired reaction mixtures were incubated for $30 \mathrm{~min}$ in air and in nitrogen and the percent decrease in conversion of hormona! iodine to origin material and iodide resulting from hypoxia was determined. The number of experiments is shown in parentheses. origin material + iodide); (c) Methimazole inhibited the formation of iodinated origin material by normal $\left(P<0.001\right.$ for $\mathrm{T}_{4}$ and $\left.\mathrm{T}_{3}\right)$ and MPO-deficient $(P<$ 0.01 for $T_{4}$ and $T_{3}$ ) leukocytes; $(d)$ Methimazole increased deiodination by normal leukocytes $(P<0.001$ for $T_{4}$ and $\left.T_{3}\right)$ but not of MPO-deficient leukocytes $\left(P>0.20\right.$ for $T_{4}$ and $\left.T_{8}\right)$. Methimazole also was without effect on the deiodination of $T_{4}$ and $T_{3}$ by phagocytosing leukocytes from three patients with CGD (B. B., D. C., R. C.) (not shown); (e) The deiodination of $T_{4}$ and $T_{3}$ by phagocytosing leukocytes in the presence of methimazole is essentially abolished by the deletion of either the leukocytes or zymosan from the reaction mixture.

Effect of hypoxia. Table III demonstrates the inhibitory effect of hypoxia on thyroid hormone degradation by normal leukocytes, by normal leukocytes treated with azide or methimazole and by MPO-deficient leukocytes. The failure of oxygen deprivation to abolish hormone degradation may be due to the incomplete removal of oxygen by the gassing procedure or to the presence of an oxygen-independent degrading system.

Effect of light. Degradation of $\mathrm{T}_{4}$ and $\mathrm{T}_{3}$ by phagocytosing leukocytes was unaffected by the use of incubation 
vials which were completely coated with electrician's tape to prevent the entrance of light.

\section{DISCUSSION}

A number of investigators have reported the degradation of the thyroid hormones by $\mathrm{H}_{2} \mathrm{O}_{2}$ and either $\mathrm{HRP}$ (21, $22,38)$ or MPO $(21,22)$ with the conversion of a portion of the hormonal iodine to inorganic iodide. The finding that $T_{4}$ or $T_{3}$ can replace a halide as the cofactor in the MPO-mediated antimicrobial system (3), and the observation that the disappearance rate of the thyroid hormones from serum is accelerated by infection (39-41) prompted a reexamination of MPO-catalyzed thyroid hormone degradation. Our findings confirm the degradation of $\mathrm{T}_{4}$ and $\mathrm{T}_{3}$ by $\mathrm{MPO}$ and $\mathrm{H}_{2} \mathrm{O}_{2}$ with the formation of origin material and iodide. The labeled origin material presumably results, in part, from the utilization of the released iodide for the iodination of protein, a reaction known to be catalyzed by $\mathrm{MPO}$ and $\mathrm{H}_{2} \mathrm{O}_{2}$ and to occur more readily at an acid $\mathrm{pH}$ (3). In our experiments, the release of inorganic iodide from $T_{4}$ and $T_{3}$ by MPO and $\mathrm{H}_{2} \mathrm{O}_{2}$ occurred more readily at $\mathrm{pH} 7.0$ than at $\mathrm{pH} 5.0$ suggesting a more alkaline $\mathrm{pH}$ optimum for this reaction. When $T_{4}$ was employed, more labeled origin material was formed at $\mathrm{pH} 5.0$ than at $\mathrm{pH} 7.0$ which is compatible with the acid $\mathrm{pH}$ optimum of the iodination reaction ( 3 ). When $T_{3}$ was employed, the $a b-$ solute amount of iodinated origin material decreased as the $\mathrm{pH}$ was lowered below 6.5 ; this may be due in part to the limitation placed on the iodination reaction by the low levels of inorganic iodide released from $T_{3}$ at acid $\mathrm{pH}$. The ratio of origin material to iodide was approximately one at $\mathrm{pH} 5.0$ with both $\mathrm{T}_{4}$ and $\mathrm{T}_{\mathbf{3}}$. The degradation of the thyroid hormones was abolished by heat-inactivation of MPO indicating its enzymic nature, and was inhibited by azide, cyanide, ascorbic acid, and propylthiouracil, agents which inhibit most peroxidasecatalyzed reactions although their activity is not limited to this effect. Methimazole, which inhibits iodination by MPO and $\mathrm{H}_{2} \mathrm{O}_{2}$, had a stimulatory effect on deiodination by this system. This effect of methimazole was not observed when MPO was replaced by HRP or LPO; indeed, thyroid hormone degradation was inhibited by methimazole when the latter enzymes were employed.

Studies with intact human leukocytes confirmed that resting cells had a low level of hormone degrading activity $(40,42)$ but revealed a striking augmentation of $T_{4}$ and $T_{3}$ degradation by phagocytosis. A tentative scheme for this process is as follows. $T_{4}$ and $T_{3}$ bind to leukocytes $(20,43,44)$. In a previous study employing incubation conditions identical to those used here, most of the labeled $T_{4}$ or $T_{3}$ was associated with leukocytes even when resting cells were employed (20). Although the exact locus of hormone fixation is not known, surface binding sites on the plasma membrane may be involved. Since the membrane of the phagocytic vacuole is, in part, invaginated cell membrane, a portion of the bound hormone would be introduced into the vacuole by phagocytosis. $T_{4}$ and $T_{s}$ also bind to the opsonized particles (20) and thus may be carried into the vacuole with the particles. Binding to the cells and particles (20), and subsequent degradation (Fig. 6), is inhibited by serum, presumably due to the presence of competing protein binding sites in the extracellular fluid.

MPO is released into the phagocytic vacuole during the degranulation process, and $\mathrm{H}_{2} \mathrm{O}_{2}$ is formed as a result of the respiratory burst associated with phagocytosis. Therefore, it might be expected, in view of the rapid degradation of the thyroid hormones by $\mathrm{MPO}$ and $\mathrm{H}_{2} \mathrm{O}_{2}$, that this system would be involved in the degradation of $T_{4}$ and $T_{3}$ in the intact cell. When MPO-deficient leukocytes were employed or when agents such as azide or cyanide, which largely inhibit degradation by the isolated MPO- $\mathrm{H}_{2} \mathrm{O}_{2}$ system, were added to normal cells, degradation of $T_{4}$ and $T_{s}$ was depressed, suggesting that an MPO-dependent hormone-degrading system does exist; however, the considerable hormone-degrading capacity which remained when MPO was absent or inhibited implies the existence of an MPO-independent system or systems. Inhibition of deiodination by ascorbic acid and by propylthiouracil was greater than inhibition by azide and cyanide, suggesting that the former inhibitors may affect both the MPO-dependent and MPO-independent systems. Formation of iodinated origin material was inhibited to a greater degree by azide and cyanide than was deiodination. The stimulation of the hormone breakdown by methimazole, so striking in the isolated $\mathrm{MPO}-\mathrm{H}_{2} \mathrm{O}_{2}$ system, could also be demonstrated in intact normal cells but did not occur in MPO-deficient cells again suggesting that thyroid hormone degradation by normal leukocytes is due, in part, to MPO.

The nature of the MPO-independent hormone degrading system(s) in intact leukocytes is unknown. $\mathrm{H}_{2} \mathrm{O}_{2}$ can degrade the thyroid hormones nonenzymatically under appropriate conditions $(45-47)$. Hormone degradation by intact leukocytes is low under conditions in which $\mathrm{H}_{2} \mathrm{O}_{2}$ formation is reduced. Thus degradation by normal or MPO-deficient leukocytes is inhibited by hypoxia and degradation by CGD leukocytes is low. When MPO is inhibited or absent, more $\mathrm{H}_{2} \mathrm{O}_{2}$ is available for non-MPOcatalyzed reactions $(20,48)$. Although these data are compatible with the involvement of $\mathrm{H}_{2} \mathrm{O}_{2}$ in MPO-independent hormone-degrading systems, they are by no means proof of such involvement. It seems unlikely that a light-activated FMN-dependent system $(49,50)$ is involved, since the removal of light did not affect degradation by intact cells.

It is possible that a portion of the thyroid hormone 
degradation observed when intact leukocytes are incubated with preopsonized particles occurs in the extracellular fluid due to the release of $\mathrm{H}: \mathrm{O}:$, MPO, or other components by cellular disruption or by a secretion process. The conversion of iodide to organic form by phagocytosing leukocytes in the presence of serum probably occurs, in part, in the extracellular fluid (20). Our studies also do not exclude the degradation of $T_{4}$ and $T_{3}$ in part or totally in the extravacuolar cytoplasm.

The major products of hormone breakdown were inorganic iodide and iodinated material which did not migrate in the solvent systems used. $T_{\mathbf{3}}$ is reported to account for about $\frac{1}{3}$ of the $T$ \& breakdown in vivo (51) while the recovery in the system studied here was much less, possibly due, in part, to the rapid degradation of $\mathrm{T}_{3}$ by the same system. At least two possible mechanisms exist for the formation of iodinated origin material. Inorganic iodide is converted in part to a water insoluble, TCA precipitable form by phagocytosing leukocytes $(3,27)$. Iodide liberated in the phagocytic vacuole by MPO dependent or independent mechanisms would be expected to be utilized, in part, in this way and thus contribute to the formation of iodinated origin material. However, this mechanism probably does not account for all of the iodoprotein formed since iodinated origin material was still detected in the presence of inhibitors at concentrations which completely inhibit conversion of iodide to organic form (27). A probable alternative mechanism for iodoprotein formation is the transfer of hormonal iodine directly to protein without the intermediate formation of iodide (52).

Thyroid hormone deiodination is inhibited by propylthiouracil in the intact animal (53-56); this agent also inhibits deiodination by isolated leukocytes. Methimazole, however, stimulates the deiodination of $T_{3}$ and $T_{4}$ by MPO and $\mathrm{H}_{2} \mathrm{O}_{2}$ or by intact leukocytes, and several studies have shown no effect of methimazole on $\mathrm{T}_{4}$ degradation in vivo $(55,57,58)$. The possibility remains that a portion of the hormone metabolism in vivo is stimulated by methimazole, analogous to the MPO system, but is balanced by an inhibitory effect of methimazole on other hormone metabolizing systems, analogous to its effect on degradation by HRP or LPO and $\mathrm{H}_{2} \mathrm{O}_{2}$.

The degradation of $\mathrm{T}_{4}$ and $\mathrm{T}_{3}$ by intact leukocytes may contribute significantly to hormone metabolism during infection. Certainly the capacity of phagocytosing cells to metabolize $T_{4}$ and $T_{3}$, as shown in studies in which high concentrations of stable hormones were employed, is sufficient to have an important impact on hormone turnover. It is probable that the accelerated hormone turnover during bacterial infection in man (39) and in Rhesus monkeys $(40,41)$ is due in part at least to the breakdown of the hormones by phagocytosing cells. The labeled iodine of $\left[{ }^{131} \mathrm{I}\right] \mathrm{T}_{4}$ is localized in areas of acute bacterial infection in man (59). This may be due, in part, to the binding of the thyroid hormones by leukocytes and to the fixation of iodine by the cell in covalent linkage. An association between myxedema coma and pneumonia has been reported (60) and the comatose state may be precipitated by the leukocytic degradation of the small amount of remaining thyroid hormone under these conditions.

It is probable that a number of substances, some as yet unidentified, combine to meet the cofactor requirement of the MPO-mediated antimicrobial system. Chloride is present in the leukocyte in considerable excess and thus may meet the bulk of this requirement. Iodide, being much more effective than chloride on a molar basis, would be expected to contribute to the cofactor pool although its low concentration may limit this contribution. The degradation of $T_{4}$ and $T_{3}$ by intact phagocytosing leukocytes with the transfer of a portion of the iodine to fixed material suggests that the mechanism for the involvement of the thyroid hormones in microbicidal activity exists and is active. However, the utilization of the thyroid hormones in the microbicidal activity of the cell has not yet been demonstrated. In preliminary studies, the staphylocidal activity of isolated leukocytes from five patients with hypothyroidism was not significantly different from that of control cells (20) suggesting that the serum thyroid hormone levels can be reduced considerably without an impairment of microbicidal activity. When the iodine supply is diminished, the concentration of chloride and other cofactors may be adequate for the peroxidase system, and this may combine with the other antimicrobial systems in the leukocyte (e.g., $\mathrm{H}_{2} \mathrm{O}_{2}$ acting independently of MPO, acid, lysozyme, lactoferrin, cationic proteins) to maintain normal microbicidal activity.

\section{ACKNOWLEDGMENTS}

We would like to thank Mrs. Ann Waltersdorph, Miss Joanne Fluvog, and Mrs. Ann Weinmann for their valuable technical assistance. The project was supported in part by Grants AI 07763, AM 1000, and AM 15810 from the U. S. Public Health Service.

\section{REFERENCES}

1. Klebanoff, S. J., and R. G. Luebke. 1965. The antilactobacillus system of saliva. Role of salivary peroxidase. Proc. Soc. Exp. Biol. Med. 118: 483.

2. Klebanoff, S. J., W. H. Clem, and R. G. Luebke. 1966. The peroxidase-thiocyanate-hydrogen peroxide antimicrobial system. Biochim. Biophys. Acta. 117: 63 .

3. Klebanoff, S. J. 1967. Iodination of bacteria: a bactericidal mechanism. J. Exp. Med. 126: 1063.

4. McRipley, R. J., and A. J. Sbarra. 1967. Role of the phagocyte in host-parasite interactions. XII. Hydrogen peroxide-myeloperoxidase bactericidal system in the phagocyte. J. Bacteriol. 94 : 1425. 
5. Klebanoff, S. J. 1968. Myeloperoxidase-halide-hydrogen peroxide antibacterial system. J. Bacteriol. 95: 2131.

6. Lehrer, R. I. 1969. Antifungal effects of peroxidase systems. J. Bacteriol. 99 : 361.

7. Klebanoff, S. J. 1970. Myeloperoxidase-mediated antimicrobial systems and their role in leukocyte function. In Biochemistry of the Phagocytic Process : Localization and the Role of Myeloperoxidase and the Mechanism of the Halogenation Reaction. J. Schultz, editor. North Holland Publishing Co., Amsterdam. 89.

8. Belding, M. E., S. J. Klebanoff, and C. G. Ray. 1970. Peroxidase-mediated virucidal systems. Science (Wash. D. C.). $167: 195$.

9. Jacobs, A. A., I. E. Low, B. B. Paul, R. R. Strauss, and A. J. Sbarra. 1972. Mycoplasmacidal activity of peroxidase- $\mathrm{H}_{2} \mathrm{O}_{2}$-halide systems. Infect. Immun. 5: 127.

10. Schultz, J., R. Corlin, F. Oddi, K. Kaminker, and W. Jones. 1965. Myeloperoxidase of the leucocyte of normal human blood. III. Isolation of the peroxidase granule. Arch. Biochem. Biophys. 111: 73 .

11. Bainton, D. F., and M. G. Farquhar. 1968. Differences in enzyme content of azurophil and specific granules of polymorphonuclear leukocytes. II. Cytochemistry and electron microscopy of bone marrow cells. J. Cell Biol. 39: 299.

12. Dunn, W. B., J. H. Hardin, and S. S. Spicer. 1968. Ultrastructural localization of myeloperoxidase in human neutrophil and rabbit heterophil and eosinophil leukocytes. Blood J. Hematol. $32: 935$.

13. Baggiolini, M., J. G. Hirsch, and C. de Duve. 1969. Resolution of granules from rabbit heterophil leukocytes into distinct populations by zonal sedimentation. J. Cell Biol. 40 : 529.

14. Baehner, R. L., M. J. Karnovsky, and M. L. Karnovsky. 1968. Degranulation of leukocytes in chronic granulomatous disease. J. Clin. Invest. 48: 187.

15. Iyer, G. Y. N., D. M. F. Islam, and J. H. Quastel. 1961. Biochemical aspects of phagocytosis. Nature (Lond.). 192: 535.

16. Klebanoff, S. J., and L. R. White. 1969. Iodination defect in the leukocytes of a patient with chronic granulomatous disease of childhood. N. Engl. J. Med. 280: 460.

17. Mandell, G. L., and E. W. Hook. 1969. Leukocyte bactericidal activity in chronic granulomatous disease: correlation of bacterial hydrogen peroxide production and susceptibility to intracellular killing. J. Bacteriol. 100: 531.

18. Wilson, D. L., and J. F. Manery. 1949. The permeability of rabbit leucocytes to sodium, potassium and chloride. J. Cell. Comp. Physiol. 34: 493.

19. Stolc, V. 1971. Stimulation of iodoproteins and thyroxine formation in human leukocytes by phagocytosis. Biochem. Biophy's. Res. Commun. 45 : 159.

20. Klebanoff, S. J., and C. B. Hamon. 1972. Role of myeloperoxidase-mediated antimicrobial systems in intact leukocytes. J. Reticuloendothel. Soc. 12: 170.

21. Björkstén, F., R. Gräsbeck, R. Karlsson, and B.-A. Lamberg. 1963. Peroxidase-catalyzed iodination and deiodination of iodotyrosines and iodothyronines. Ann. Med. Exp. Biol. Fenn. 41: 156.

22. Björkstén, F. 1966. The peroxidase-catalyzed oxidation of thyroxine. Acta Chem. Scand. $20: 1438$.

23. Woeber, K. A., and S. H. Ingbar. 1972. Stimulation by phagocytosis of $\mathrm{L}$-thyroxine $\left(\mathrm{T}_{4}\right)$ deiodination in human leukocytes. Clin. Res. $20: 445$.

24. Klebanoff, S. J., and W. L. Green. 1972. Metabolism of thyroid hormones by phagocytizing human leukocytes. J. Clin. Invest. 51 : 51a. (Abstr.)

25. Woeber, K. A., G. F. Doherty, and S. H. Ingbar. 1972. Stimulation by phagocytosis of the deiodination of Lthyroxine in human leukocytes. Science (Wash. D. C.). 176: 1039.

26. Lehrer, R. I., and M. J. Cline. 1969. Leukocyte myeloperoxidase deficiency and disseminated candidiasis: the role of myeloperoxidase in resistance to Candida infection. J. Clin. Invest. $48: 1478$.

27. Pincus, S. H., and S. J. Klebanoff. 1971. Quantitative leukocyte iodination. N. Engl. J. Med. 284: 744.

28. Agner, K. 1958. Crystalline myeloperoxidase. Acta Chem. Scand. 12: 89.

29. Morrison, M., and D. E. Hultquist. 1963. Lactoperoxidase. II. Isolation. J. Biol. Chem. 238: 2847.

30. Klebanoff, S. J. 1965. Inactivation of estrogen by rat uterine preparations. Endocrinology. 76: 301.

31. Root, R. K., and T. P. Stossel. 1972. Intracellular site of iodination by granulocytes (PMN). Clin. Res. 20: 536.

32. Quie, P. G., J. G. White, B. Holmes, and R. A. Good. 1967. In vitro bactericidal capacity of human polymorphonuclear leukocytes: diminished activity in chronic granulomatous disease in childhood. J. Clin. Invest. 46: 668.

33. Holmes, B., A. R. Page, and R. A. Good. 1967. Studies of the metabolic activity of leukocytes from patients with a genetic abnormality of phagocytic function. $J$. Clin. Invest. 46: 1422.

34. Grignaschi, V. J., A. M. Sperperato, M. J. Etcheverry, and A. J. L. Macario. 1963. Un nuevo cuadro citoquimico: negatividad espontanea de las reacciones de peroxidasas, oxidasas y lipido en la progenie neutrofila y en los monocitos de dos hermanos. Rev. Assoc. Med. Argent. $77: 218$.

35. Undritz, E. 1966. Die Alius-Grignaschi-Anomalie: der erblich-konstitutionelle Peroxydasedefekt der Neutrophilen und Monozyten. Blut Z. Gesamte Blutforsch. 14: 129.

36. Lehrer, R. I., J. Hanifin, and M. J. Cline. 1969. Defective bactericidal activity in myeloperoxidase-deficient human neutrophils. Nature (Lond.). 223: 78.

37. Klebanoff, S. J. 1970. Myeloperoxidase: contribution to the microbicidal activity of intact leukocytes. Science (Wash. D. C.). 169: 1095.

38. Mayrargue-Kodja, A., S. Bouchilloux, and S. Lissitzky. 1958. Action d'une peroxydase vegetale sur divers amino acides phénoliques: tyrosine, thyronine et certains de leurs dérivés iodés ou hydroxylés. Bull. Soc. Chim. Biol. 40: 815.

39. Gregerman, R. I., and N. Solomon. 1967. Acceleration of thyroxine and triiodothyronine turnover during bacterial pulmonary infections and fever: implications for the functional state of the thyroid during stress and senescence. J. Clin. Endocrinol. Metab. $27: 93$.

40. Woeber, K. A. 1971. Alterations in thyroid hormone economy during acute infection with Diplococcus pneumoniae in the rhesus monkey. J. Clin. Invest. 50: 378.

41. DeRubertis, F. R., and K. A. Woeber. 1972. Evidence for enhanced cellular uptake and binding of thyroxine in vivo during acute infection with Diplococcus pneumoniae. J. Clin. Invest. $51: 788$.

42. Reinwein, D., and H. A. Durrer. 1969. Deiodination of thyroxine by erythrocytes and leukocytes from euthyroid and hyperthyroid patients. Horm. Mctab. Res. 1: 241. 
43. Roche, J., M. W. Hamolsky, R. Michel, and H. Lotz. 1962. Concerning the fixation of the thyroid hormones and their acetic acid derivatives by horse leukocytes in vitro. C. R. Hebd. Seances Acad. Sci. Ser. D Sci. Nat. (Paris). $255: 1278$.

44. Siegel, E., and B. A. Sachs. 1964. In vitro leukocyte uptake of ${ }^{131}$ I labeled iodide, thyroxine and triiodothyronine, and its relation to thyroid function. J. Clin. Endocrinol. Metab. $24: 313$.

45. Galton, V. A., and S. H. Ingbar. 1963. Role of peroxidase and catalase in the physiological deiodination of thyroxine. Endocrinology. 73: 596.

46. Reinwein, D., and J. E. Rall. 1966. Nonenzymatic deiodination of thyroxine by hydrogen peroxide. Endocrinology. 78: 1248.

47. Reinwein, D., J. E. Rall, and H. A. Durrer. 1968. Deiodination of thyroxine by a hydrogen peroxide generating system. Endocrinology. 83: 1023.

48. Klebanoff, S. J., and S. H. Pincus. 1971. Hydrogen peroxide utilization in myeloperoxidase-deficient leukocytes: a possible microbicial control mechanism. J. Clin. Invest. 50: 2226 .

49. Galton, V. A., and S. H. Ingbar. 1962. A photoactivated flavin-induced degradation of thyroxine and related phenols. Endocrinology. 70: 210.

50. Reinwein, D., and J. E. Rall. 1966. Nonenzymatic deiodination of thyroid hormones by flavin mononucleotide and light. J. Biol. Chem. $241: 1636$.

51. Sterling, K., M. A. Brenner, and E. S. Newman. 1970.
Conversion of thyroxine to triiodothyronine in normal human subjects. Science (Wash. D. C.). 169: 1099.

52. Galton, V. A., and S. H. Ingbar. 1961. The mechanism of protein iodination during the metabolism of thyroid hormones by peripheral tissues. Endocrinology. 69: 30 .

53. Van Arsdel, P. P., Jr., and R. H. Williams. 1956. Effect of propylthiouracil on degradation of $\mathrm{I}^{131}$-labeled thyroxine and triiodothyronine. Am. J. Physiol. 186: 440.

54. Van Middlesworth, L., and S. L. Jones. 1961. Interference with deiodination of some thyroxine analogues in the rat. Endocrinology. 69: 1085.

55. Hershman, J. M., and L. Van Middlesworth. 1962. Effect of antithyroid compounds on the deiodination of thyroxine in the rat. Endocrinology. 71: 94.

56. Hershman, J. M. 1964. Effect of 5 and 6 propylthiouracil on the metabolism of L-thyroxine in man. J. Clin. Endocrinol. Metab. 24: 173.

57. Ballantine, J. J., and L. Oliner. 1968. Failure of methimazole to affect peripheral thyroid indices in man. Proc. Soc. Exp. Biol. Med. 127: 388.

58. Nicoloff, J. T. 1970. A new method for the measurement of acute alterations in thyroxine deiodination rate in man. J. Clin. Invest. 49: 267.

59. Adelberg, H. M., J. K. Siemsen, R. C. Jung, and J. T. Nicoloff. 1971. Scintigraphic detection of pulmonary bacterial infections with labeled thyroid hormones and pertechnetate. Radiology. 99 : 141.

60. Hausmann, W., and A. J. Karlish. 1961. Acute myxoedema precipitated by pneumonia. Report of five cases. Br. Med.J. 2: 1063. 